\title{
Impact of Moistened Bio-insulation on Whole Building Energy Use
}

\author{
Eshrar Latif ${ }^{1,}$, Devapriya Chitral Wijeyesekera ${ }^{2}$, and Shaghayegh Mohammad $^{3}$ \\ ${ }^{1}$ Welsh School of Architecture, Cardiff University, Cardiff, United Kingdom \\ ${ }^{2}$ Faculty of Civil and Environmental Engineering, Universiti Tun Hussein Onn Malaysia, Johor, \\ Malaysia \\ ${ }^{3}$ Department of Architecture and Civil Engineering University of Bath, Bath, United Kingdom
}

\begin{abstract}
One of the key properties of hemp insulation is its moisture adsorption capacity. Adsorption of moisture can increase both thermal conductivity and heat capacity of the insulation. The current study focuses on the effect of moisture induced thermal mass of installed hemp insulation on the whole building energy use. Hygrothermal and thermal simulations were performed using the CIBSE TRY weather data of Edinburgh and Birmingham with the aid of following simulation tools: WUFI and IES. Following simplified building types were considered: building-1 with dry hemp wall and loft insulations, building- 2 with moistened hemp wall and loft insulation and building-3 with stone wool insulation. It was observed that the overall conditioning load of building- 1 was 1.2 to $2.3 \%$ higher than building-2 and 3. However, during the summer season, the cooling load of building-2 was $3-7.5 \%$ lower than the other buildings. It implies that, moistened insulation can potentially mitigate the effect of increasing cooling degree days induced by global warming.
\end{abstract}

\section{Introduction}

Construction materials comprises $40-50 \%$ of worldwide annual material use [1] and the building industry accounts for the second highest consumption of raw materials , after food production.. Environmental impact of material consumption is manifold including resource depletion, waste production, disposal at the end of lifecycle, consumption of water and energy and emission of pollutants [2]. The seven core principles that defines the sustainability of construction are reducing resource consumption, reusing resources, using recyclable resources, protecting nature, eliminating toxics, applying life cycle costing, and focusing on quality [3]. One study shows that [4] a correct choice of building materials can reduce almost $30 \% \mathrm{CO} 2$ emissions. Therefore, it is imperative that construction materials should be used responsibly for the greater good of the environment.

Natural materials from both renewable and non-renewable resources have generally lower embodied energy and toxicity than man-made materials as they require less processing [5]. Amongst these, the materials that are derived from renewable sources can

\footnotetext{
*Corresponding author: latife@ $@$ cardiff.ac.uk
} 
be considered as sustainable and green materials [6]. Plants can be a source of renewable and green materials if cultivated and harvested on a sustainable basis [7]. Furthermore, if produced locally, plant-based building materials will require less energy during transportation. Morel et al. [8]finds that it is possible to reduce the building energy by $215 \%$ through the use of local materials. Additionally, plant based materials work as a carbon sink during their growing period and they are biodegradable at the end of their life cycle. For all these attributes, plant based can be considered as material with low carbon [4] and low ecological footprint [7].

Plant fibres and shives can be used to manufacture thermal insulation taking advantage of their pore structure, elasticity and moisture and pollutant adsorption capacity[9, 7]. Wheat, rye, barley, oats, elephant grass, cotton, Hemp, maize, reed, flax and coconut are some of these plant-based materials used in building industry [10].

However, there is widespread concern that bio-insulations may perform poorly if they adsorb a lot of moisture. On the contrary, there is also belief that moistened bio-insulations might have increased thermal mass in highly insulated buildings which could be useful at certain boundary conditions. The Insulations used in the walls and loft of a "Passivhaus" are thicker than the insulation incorporated in a conventional house to meet the fabric heat loss requirements set for the Passivhaus. If hemp insulation is used in a vapour open construction with the thickness of insulation resembling that of a Passivhaus, it can be assumed that the thicker hemp insulation will work as a hygric and thermal mass and will influence the amount of heating and cooling load of the building. This assumption was tested for the weather conditions of Edinburgh and Birmingham using hygrothermal and thermal simulation tools.

\section{Materials and methods}

Hemp-2 and stone wool insulations were selected for the study. The summarised material properties are provided in Table 1 below. Notably, the mean density and declared Specific Heat Capacity of Hemp-2 are nearly double that of Stone wool while the measured mean thickness of Stone wool is double that of Hemp-2. However, the declared Dry Thermal Conductivities for both have very similar values.

Table 1. Summary Properties of the Insulations.

\begin{tabular}{|c|c|c|l|c|c|}
\hline Materials & $\begin{array}{c}\text { Measured } \\
\text { Mean dry } \\
\text { Density } \\
\left(\mathrm{kg} / \mathrm{m}^{3}\right)\end{array}$ & $\begin{array}{c}\text { Measured } \\
\text { Mean } \\
\text { Thickness } \\
(\mathrm{mm})\end{array}$ & $\begin{array}{c}\text { Constituents } \\
\text { Specific Heat } \\
\text { Capacity } \\
(\mathrm{J} / \mathrm{Kg} . \mathrm{K})\end{array}$ & $\begin{array}{c}\text { Declared Dry } \\
\text { Thermal } \\
\text { Conductivity } \\
\text { (W/m.K) }\end{array}$ \\
\hline $\begin{array}{c}\text { Stone } \\
\text { Wool }\end{array}$ & 23 & $100-110$ & $\begin{array}{l}\text { Amphibolite, } \\
\text { about 6\% lime stone, } \\
\text { about 9\% calcium oxide, } \\
\text { resin }\end{array}$ & 850 & 0.038 \\
\hline Hemp-2 & 50 & 55 & $\begin{array}{l}85 \% \text { hemp fibres, 10-12\% } \\
\text { bi-component fibres and } \\
3-5 \% \text { soda. }\end{array}$ & 1600 & 0.038 \\
\hline
\end{tabular}

Two different numerical tools were used in this study. These are: (i) The WUFI software, and (ii) The IES (Integrated Environmental Solution) Virtual Environment software. The WUFI software [11] has been used for hygrothermal simulation. The IES virtual environment is a software package consisting of a number of energy related simulation tools to address dynamic thermal properties, air flow, lighting, lifecycle analysis, computational fluid dynamics etc. in relation to buildings. The dynamic thermal simulation was performed by the ApacheSim software tool with solar shading analysis done 
by the SunCast and air flow by infiltration and ventilation calculated by the Macroflow tool.All of these are packages within the IES software. The IES uses the transient heat balance equations in its algorithm. The further details of the governing equation can be found in the website of IES [12].

To determine the effect of moisture adsorption by hemp-2 insulation on the whole house energy use in Edinburgh, the following method was used:

- Hygrothermal simulation was carried out in the WUFI software for the weather condition in Edinburgh. CIBSE TRY weather data were used in the simulation.

- From the analysed data of water content in the hemp-2 insulation, average water content in the insulation was determined. The water content was determined as $7.6 \mathrm{~kg} / \mathrm{m}^{3}$.

- From average water content of the insulation, the density and the heat capacity of the (hemp insulation and water) matrix was determined. The modified density of the moistened insulation was determined as $57.6 \mathrm{~kg} / \mathrm{m}^{3}$ and the modified heat capacity was calculated as $1943 \mathrm{~J} / \mathrm{kg} . \mathrm{K}$ based on the heat capacity of water as $4200 \mathrm{~J} / \mathrm{kg}{ }^{\circ} \mathrm{K}$.

- For the purpose of simplification, similar water content data was used for Birmingham during the input of hemp-2 material data in the IES software.

The instrumented wall section and the moisture content variations in the insulation are shown in Fig.1 and Fig. 2, respectively. The buildings incorporated dry hemp-2, moistened hemp-2 and stone wool insulations are henceforth called as building-1, building- 2 and building-3, respectively.

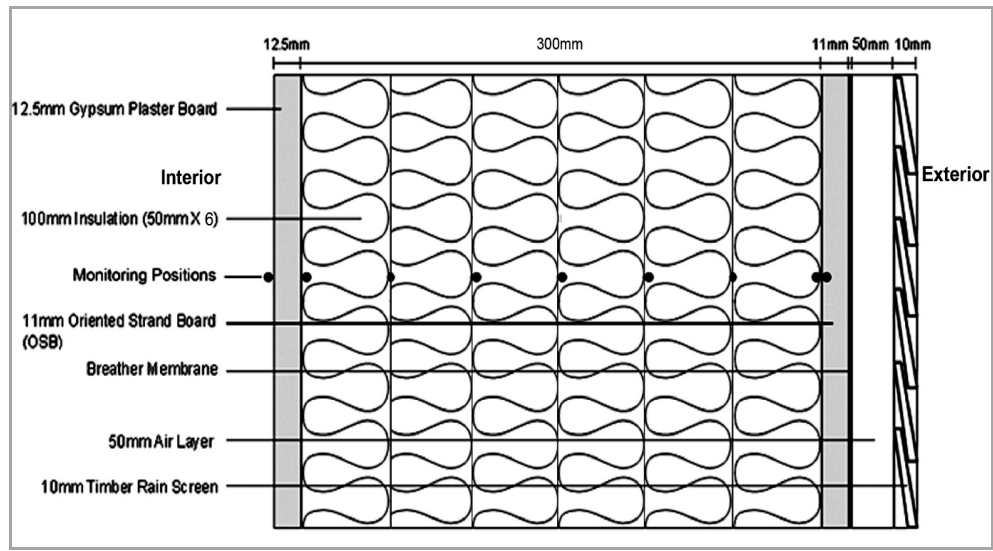

Fig. 1. The wall section.

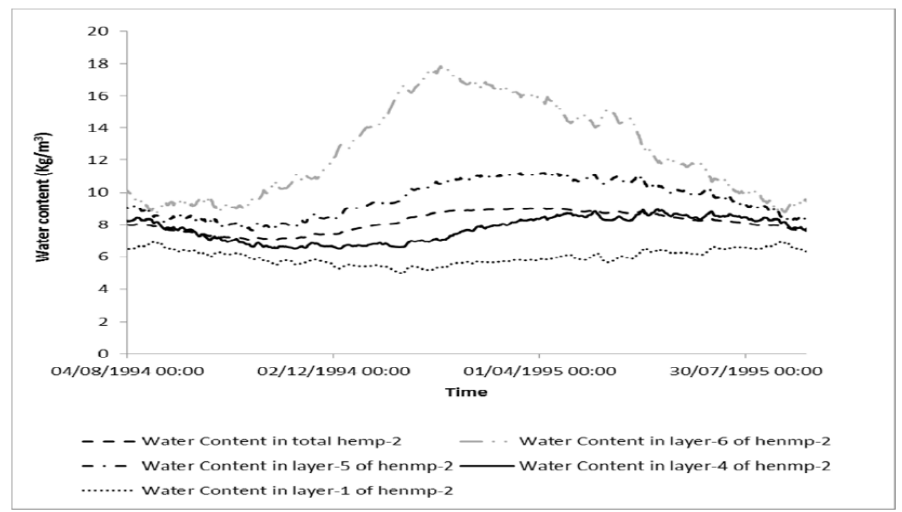

Fig. 2. Moisture content variations in hemp-2 insulation. 
Dynamic thermal simulation was run in the IES Virtual Environment 2012 for three notional houses incorporating dry hemp, moistened hemp and stone wool insulation for the weather condition in Edinburgh and Birmingham. The simulation was run for one year with a preconditioning period of sixty days.

The plan and the IES software image of the buildings are shown in Fig. 3 and Fig. 4, respectively. As shown in Fig. 3, the notional building has two windows in the south wall with each window having the dimension of dimension of $(2 \mathrm{X} 2) \mathrm{m}$. There is a door in the north wall. The height of the building is $7 \mathrm{~m}$, the ground floor is $4 \mathrm{~m}$ and the loft space is 3 $\mathrm{m}$.

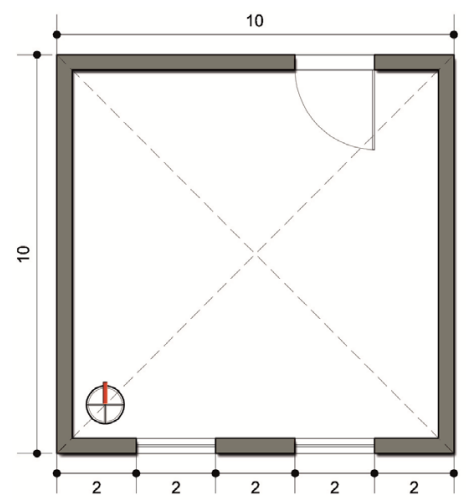

Fig. 3. The plan of the notional building for the IES software.

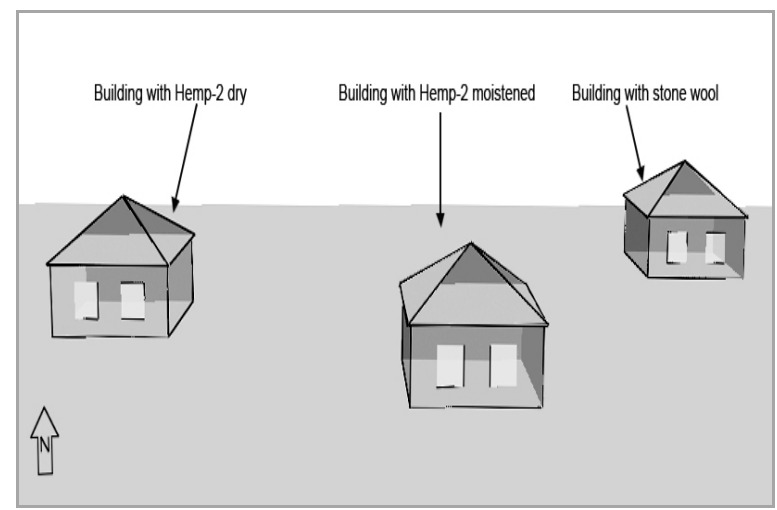

Fig. 4. The IES software image of the simulated buildings.

\section{Results and discussion}

Fig. 5 to Fig. 7 show the space conditioning sensible loads for the selected buildings for the weather conditions in Edinburgh and Birmingham. It can be observed that, in Edinburgh, the space conditioning sensible load of building- 2 is $2.3 \%$ and $2.1 \%$ higher than that of building- 1 and building-3, respectively. In Birmingham, the space conditioning sensible load of building- 2 is $2.27 \%$ and $1.2 \%$ higher than that of building- 1 and building-3, respectively. However, a closer observation of the monthly space conditioning loads revealed that, in Edinburgh, in summer time of June, July and August, the space conditioning sensible load of building- 2 is lower than that of building- 3 by $4 \%$ and higher 
than that of building-1 by $1.97 \%$. In Birmingham, for the summer time of June, July and August, the space conditioning sensible load of building- 2 is lower than that of building-3 by $7.5 \%$ and higher than that of building- 1 by $1.75 \%$. Thus, the moistened hemp-2 insulation is performing better than the stone wool insulation during the summer months. It can be assumed that, the heat capacity of the moistened hemp-2 insulation can be fully utilized when cooling degree days increase due to the global warming.

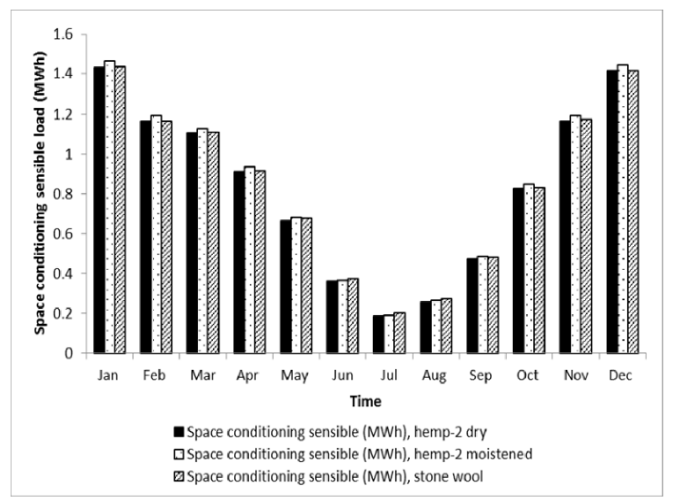

Fig. 5. The monthly space conditioning sensible loads of the selected buildings in Edinburgh.

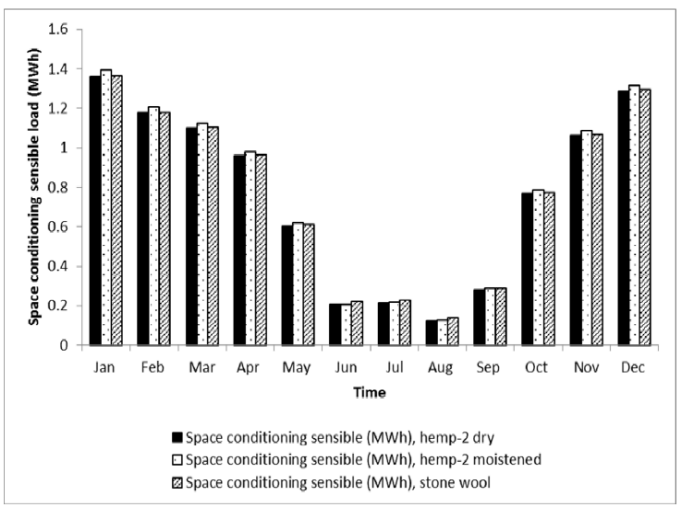

Fig. 6. The monthly space conditioning sensible loads of the selected buildings in Birmingham.

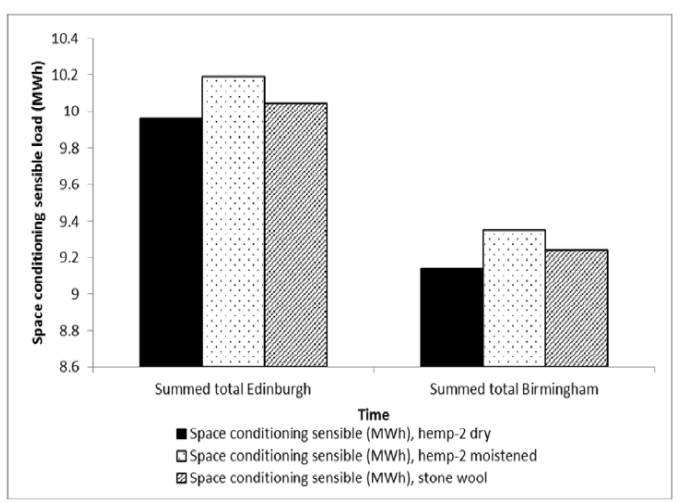

Fig. 7. The yearly space conditioning sensible loads of the selected buildings in Edinburg and Birmingham, respectively. 


\section{Conclusions}

The objective of the study was to examine the effect of thermal mass of moistened hemp-2 insulation on whole building energy use. It was found that, the total space conditioning load of building-2 (with moistened hemp-2 insulation) was higher than that of building-1 (with dry hemp-2 insulation) and building-3 (with stone wool insulation) by $2.3 \%$ and $2.1 \%$, respectively, in Edinburgh and $2.27 \%$ and $1.2 \%$, respectively in Birmingham. However, it was also found that during the summer months of June, July and August the cumulative space conditioning load of building- 2 was lower than that in building-3 by $3 \%$ and $7.5 \%$ for Edinburgh and Birmingham, respectively. Based on this result, it can be said that moistened hemp insulations will be more effective in saving energy when cooling degree-days increase as a result of the global warming.

\section{References}

[1] J.B. Storey, Construction materials stewardship: The status quo in selected countries: CIB W115, Centre for Building Performance Research, Victoria University of Wellington, (2008)

[2] R. Yao, Design and management of sustainable built environments, Springer, (2013)

[3] C.J. Kibert, and K. Grosskopf, Radical sustainable construction: envisioning nextgeneration green buildings, J. of Land Use \& Environmental Law, 23(1), 145, (2007)

[4] M.J. González, and J. García Navarro, Assessment of the decrease of CO2 emissions in the construction field through the selection of materials: Practical case study of three houses of low environmental impact, Building and Environment, 41(7), 902-909, (2006)

[5] J.J. Kim, and B. Rigdon, Sustainable architecture module: Qualities, use, and examples of sustainable building materials, National Pollution Prevention Center for Higher Education, (1998)

[6] R. Spiegel, and D. Meadows, Green building material: a guide to product selection and specification, $3^{\text {rd }}$ ed., John Wiley, Hoboken, N.J., (2012)

[7] B. Berge, The ecology of building materials, $2^{\text {nd }}$ ed., Elsevier/Architectural Press, Amsterdam; Oxford, (2009)

[8] J.C. Morel, A. Mesbaha, M. Oggerob, and P. Walker, Building houses with local materials means to drastically reduce the environmental impact of construction, Building and Environment, 36, 1119-1126, (2001)

[9] E. Latif, M. Lawrence, A. Shea, and P. Walker, Moisture buffer potential of experimental wall assemblies incorporating formulated hemp-lime, Building and Environment, 93 ,199-209. (2015)

[10]A. Cripps, Crops in construction handbook, CIRIA, London, (2004)

[11]H.M. Künzel, Simultaneous heat and moisture transport in building components: Oneand two-dimensional calculation using simple parameters, Fraunhofer Institute of Building Physics, Fraunhofer Institute of Building Physics, Stuttgard, (1995)

[12]IES, ApacheSim Calculation Methods (2016), Retrieved on October 1, 2016 from http://www.iesve.com/downloads/help/Thermal/Reference/ApacheSimCalculationMet hods.pdf. 